BBA 33245

\title{
An effective method for defatting albumin using resin columns
}

Preparations of native serum albumin are known to contain varying amounts of bound fatty acid (refs. I-4; J. K. FuLLER, unpublished). To obtain fatty acid-free preparations for the study of the physical properties of albumin, several methods have been developed for removing the bound lipids ${ }^{5-8}$. It is important that the process can be carried out under conditions which are not likely to denature the protein.

We report here a method for defatting albumin in the $\mathrm{pH}$ range between 3.0 and 4.0 using buffered ion-exchange or surface adsorber resin columns. We have found this method at least comparable in effectiveness to the method using charcoal as an adsorber, which is the only other method which is carried out at these relatively mild $\mathrm{pH}$ values.

The following albumin preparations were used: bovine mercaptalbumin, batch III, and a mixture of batches I and II (8-9\% dimer; $0.72 \mathrm{SH}$ group per mole) prepared by Dr. T. E. Thompson according to the method of Hughes ANv Dintzis" which involved the addition of I mole stearic acid per mole of protein; Human mercaptalbumin $(5-6 \%$ dimer $)$ prepared by Dr. S. Allerton using the same method, except that no fatty acid was added; and crystalline bovine plasma albumin lot E7 503 (5-6\% dimer; 0.65 SH group per mole) from the Armour Pharmacentical Co.

The resins employed were: Amberlite CG-400, 100-200 mesh, chromatographic grade, from Mallinckrodt Chemical Works, a strongly basic, quaternary ammonium anion-exchange polystyrene resin; and an experimental sample of Amberlite XAI)-2, lot SW 66-o6g8, a nonexchanging polystyrene sorbent with surface area of $333 \mathrm{~m}^{2} / \mathrm{g}$, from Rohm and Haas. Darco activated charcoal was obtained from Atlas Chemical Industries. All chemicals were reagent grade; water was de-ionized.

Preparation of ion-exchange resin. Fresh, dry resin was immersed overnight in o.I $\mathrm{M} \mathrm{NaOH}$. It was then washed in water, poured into a column, and an extraction mixture containing isopropanol, heptane, and $2.5 \mathrm{M} \mathrm{H}_{2} \mathrm{SO}_{4}$ in the ratio of $40: \mathrm{Io}: \mathrm{I}$ was passed over the resin until the visible front reached the bottom of the column. Three column volumes were collected at the rate of I column vol./h. This removed shedded resin material which would otherwise titrate as fatty acid in a subsequent assay; it leaves the resin free of such material for at least 6 months. The resin was then washed with isopropanol and water, in succession, and put on the acetate cycle by passing over it a 3 -fold excess of $\mathrm{I}$.o $\mathrm{M}$ acetic acid at the rate of I column vol./h.

Procedure for removal of fatty acid from albumin. A $5 \%$ albumin solution was prepared in acetate buffer adjusted to contain o. I M acetate ion at the appropriate $\mathrm{pH}$. This solution was equilibrated by dialysis against the same buffer for 24 h at $2-5^{\circ}$. After this period some solutions showed turbidity which was removed by filtration through a $0.45-\mu$ Millipore filter or by centrifugation for 3 h at $34000 \times g$ at $10^{\circ}$. The filtered sample was then applied to a resin column, which had previously been equilibrated with the same buffer as the protein solution, by passing the buffer down the column for several hours at the flow rate at which the column was to be operated. The sample was passed down the column at a flow rate of less than 0.3 column vol./h.

Fatty acid determination. Samples were assayed for long-chain fatty acid content by the method of DOLE ${ }^{10}$, with two modifications: because the samples were buffered, 
TABLE I

EFFECTIVENESS OF FATTY ACID REMOVAL FROM ALBUMIN BY FILTRATION, By PASSING OVER A PH-CONTROLLED RESIN COLUMN, AND BY THE CHARCOAL METHOD ${ }^{10}$

\begin{tabular}{|c|c|c|c|c|c|c|c|}
\hline & \multirow[t]{2}{*}{ (I) Protein sample } & \multirow{2}{*}{$\begin{array}{l}\text { (2) Initial } \\
\text { fatty } \\
\text { acid } \\
\text { bound }\end{array}$} & \multirow{2}{*}{$\begin{array}{l}\text { (3) pH } \\
\text { of } \\
\text { acetate } \\
\text { buffer }\end{array}$} & \multirow{2}{*}{$\begin{array}{l}\text { (4) Fatty } \\
\text { acid } \\
\text { bound } \\
\text { after } \\
\text { filtration }\end{array}$} & \multirow{2}{*}{$\begin{array}{l}\text { (5) Resin } \\
\text { used in } \\
\text { column }\end{array}$} & \multicolumn{2}{|c|}{ Final fatty acid bound ${ }^{\star}$} \\
\hline & & & & & & $\begin{array}{l}\text { (6) Re- } \\
\text { sin } \\
\text { method }\end{array}$ & $\begin{array}{l}\text { (7) Charcoal } \\
\text { method }^{\star *}\end{array}$ \\
\hline $\mathbf{I}$ & $\begin{array}{l}\text { Bovine mercaptalbumin } \\
\text { (Thompson III) }\end{array}$ & I.76 & 4.8 & I. 72 & - & - & - \\
\hline 2 & & & $4 \cdot 4$ & I. 23 & - & - & - \\
\hline 3 & & & 4.0 & 0.39 & $\begin{array}{l}\mathrm{CG}-400 \\
\mathrm{XAD}-2\end{array}$ & $\begin{array}{l}0.05 \\
0.13\end{array}$ & - \\
\hline 4 & & & $3 \cdot 7$ & 0.32 & - & - & - \\
\hline 5 & & & $4.0(P)^{\star \star \star}$ & $\begin{array}{l}1.72 \\
0.88\left(7^{2} h\right)\end{array}$ & - & - & 一 \\
\hline 6 & Human mercaptalbumin & I. I & 4.0 & I.07 & $\begin{array}{l}\mathrm{CG}-400 \\
\mathrm{XAD}-2\end{array}$ & $\begin{array}{l}0.13 \\
0.29\end{array}$ & - \\
\hline 7 & $\begin{array}{l}\text { Bovine mercaptalbumin } \\
\text { (Thompson I and II) }\end{array}$ & I.9 & $3 \cdot 7$ & 一 & $\mathrm{CG}-400$ & 0.08 & $0.08\left(\mathrm{pH}_{3.0}\right)$ \\
\hline 8 & Bovine plasma albumin & 0.66 & $3 \cdot 7$ & 0.34 & $\mathrm{CG}-400$ & 0.07 & $0.3 \mathrm{I}$ \\
\hline 9 & & & 3.0 & $0.3^{8}$ & $\mathrm{CG}-400$ & $0.0 \mathbf{I}$ & $0.0 \mathrm{I}$ \\
\hline
\end{tabular}

* Moles fatty acid per mole protein

** Chen method performed at same $\mathrm{pH}$ as comparison run, except where otherwise noted.

${ }_{* \star *}$ Phosphate buffer used instead of acetate buffer.

the extraction mixture was made with $2.5 \mathrm{M}$ instead of $0.5 \mathrm{M} \mathrm{H}_{2} \mathrm{SO}_{4}$; and, to remove acetic acid from the non-aqueous phase containing the assayable material after extraction, this phase was washed 3 times with $3 \mathrm{ml}$ of $0.05 \mathrm{M}$ phosphate buffer at $\mathrm{pH} 5.5$. Since this reduced the volume of the heptane phase, 2 instead of $3 \mathrm{ml}$ were titrated.

The effectiveness of the two steps of the method in the removal of bound fatty acid from albumin is presented in Table I.

Column 4 of Table I shows that a significant reduction in bound fatty acid can be achieved for some samples in the step before resin treatment, by filtering off the turbid material produced upon equilibration in the buffer.

Williams AND Foster ${ }^{11}$ have found that in o.I $\mathrm{M} \mathrm{HCl}$ the fatty acids liberated from the albumin coagulate and float on centrifugation of the albumin solutions. However, the aggregates observed in the present studies sedimented on centrifugation and contained about $20 \%(\mathrm{w} / \mathrm{w})$ of protein, as determined by the method of LowRY et al. ${ }^{12}$. The pellet from a sample of bovine mercaptalbumin (Thompson batch III) had been twice resuspended in $\mathrm{KCl}$ and re-sedimented, prior to analysis. The fatty acid:protein ratio in the pellet would represent a mole ratio of I000: I assuming the protein to be whole albumin.

Line 5 of Table I shows that the aggregation is not merely a factor of sample and $\mathrm{pH}$, but also of the buffer anion. Line 6 shows that a sample in which there was virtually no turbidity was nevertheless defatted effectively by the resin. It is suggested that the formation of the filterable turbidity at $\mathrm{pH}$ above 3 is related to the presence of small amounts of protein impurity or partially denatured albumin, and, while providing a convenient pre-treatment, is not an essential element of the defatting 
process described here. It was noted that $\mathrm{pH}$ is an important variable in fatty acid removal, both in the formation of aggregate and in the removal of fatty acid by the resin treatment. Similar $\mathrm{pH}$ dependence had been found for removal of fatty acids by charcoal treatment in the $\mathrm{pH}$ range from 3.0 to 5.0 (ref. 8). Lines $7^{-9}$ show a comparison of the effectiveness of the resin method and the charcoal method at two $\mathrm{pH}$ values for bovine plasma albumin and bovine mercaptalbumin (Thompson batch I and II).

The non-exchanging resin $\mathrm{XAD}-2$ was found to be only slightly less effective than the ion-exchange resin $\mathrm{CG}_{-4}$ oo. On studying fatty acid-acetate exchange in acetate cycle $\mathrm{CG}-400$ resin in the range of $\mathrm{pH} 4.6$ to $\mathrm{pH} 6.5$, it was found that at the lower of these $\mathrm{pH}$ values at least some of the long-chain fatty acid bound to the resin without displacing acetate. This suggests that at the $\mathrm{pH}$ values used in the defatting of albumin, both resins act primarily as surface area sorbents for the long chain fatty acids, and that for some reason other than its exchange capacity, perhaps due to its smaller mesh size, the $\mathrm{CG}_{-400}$ is more effective than the XAD-2.

No noticeable increase in dimer content (determined by sedimentation velocity analysis on the Spinco model $\mathrm{E}$ ultracentrifuge) was observed following defatting of the albumin in either the resin or the charcoal method. However, some decrease in the sulfhydryl content (measured by a modified Ellman reaction ${ }^{13}$ ) was observed following defatting with resin treatment (approx. 10\%), and to a greater extent following charcoal treatment (approx. 20-25\%).

The authors wish to thank Miss Inger Hansen for her expert technical assistance, Dr. M. J. Hunter for her helpful advice, and the Rohm and Haas laboratories for the sample of Amberlite XAD-2 resin. Support for the work of J.K.F. was provided by U.S. Public Health Service National Institutes of Health, Biophysics Training Grant GM-I355.

Institute of Science and Technology,

W. SCHEIDER

Biophysics Research Division, University of Michigan,

J. K. FULLER

Ann Arbor, Mich. 48105 (U.S.A.)

I F. E. Kendall, J. Biol. Chem., I 38 (I94I) 97.

2 E. J. Cohn, W. L. Hughes, Jr. and J. H. Weare, J. Am. Chem. Soc., 69 (1947) 753.

3 R. S. Gordon, J R. ANd A. Cherkes, J. Clin. Invest., 35 (1956) 206.

4 A. Saifer and L. Goldman, J. Lipid Res., 2 (I96I) 268.

5 H. M. Dintzis, Ph. D. Thesis, Harvard University, I952.

6 D. S. Goodman, Science, I 25 (r957) I 296.

7 E. J. Williams and J. F. Foster, J. Am. Chem. Soc., 8 i (I959) 865.

8 R. F. Chen, J. Biol. Chem., 242 (1967) I73.

9 W. L. Hughes, JR. ANo H. M. Dintzis, J. Biol. Chem., 239 (I964) 845

IO V. P. Dole, J. Clin. Invest., 35 (1956) I 5 O.

i i F. J. Williams and) J. F. Foster, J.Am. Chem. Soc., 82 (I960) 374 I.

i 2 O. H. Lowry, N. J. Rosebrough, A. L. Farr and R. J. Randall, J. Biol. Chem., I93 (195I) 265.

i 3 J. Janatova, J. K. liuller ani M. J. Hunter, J. Biol. Chem., 243 (1968) 3612.

Received July 28 th, I $97^{\circ}$

Biochim. Biophys. Acta, 22 I (1970) $37^{6-37^{8}}$ 